\title{
Inappropriate antidiuretic hormone secretion in Wernicke's encephalopathy
}

\author{
Philip E. CoOles \\ B.Sc., M.B., M.R.C.P.
}

\author{
LESLIE J. BORTHWICK \\ M.B., M.R.C.P.
}

Aberdeen Royal Infirmary, Foresterhill, Aberdeen AB9 1GS

\begin{abstract}
Summary
A case of the syndrome of inappropriate secretion of antidiuretic hormone in association with Wernicke's encephalopathy is described, where both responded to intravenous vitamin $B$ complex. Thiamine may be life-saving in hyponatraemia with neurological signs due to Wernicke's encephalopathy.
\end{abstract}

\section{Introduction}

It has been suggested that the syndrome of inappropriate antidiuretic hormone secretion might occur in Wernicke's encephalopathy (Shalhoub and Antoniou, 1969; Ebels, 1978; Leading Article, 1979). However, the authors are unaware of published evidence for this although Ebels mentions he has such evidence in a patient. A case is reported in which reversal of the syndrome of inappropriate antidiuretic hormone secretion occurred with intravenous vitamin B complex.

\section{Case report}

A 58-year-old white man, a known alcoholic, was admitted with a story of progressive unsteadiness and confusion over 3 weeks. He had been living rough and was drowsy, disorientated, malnourished and unkempt. He was on no therapy and unable to give a history.

The dramatic physical signs were severe truncal ataxia such that the patient could not sit up in bed, a bilateral abducent nerve palsy and absent pupillary reflexes to light and accommodation. There were no stigmata of chronic liver disease or evidence of acute liver failure. He was apyrexial without meningism. There was no evidence of fluid depletion or cardiac failure but there was slight pitting oedema at the ankles. His pulse was $95 / \mathrm{min}$, regular of good volume and his blood pressure $160 / 85 \mathrm{mmHg}$.

Investigations revealed severe hyponatraemia (115 mmol/l), a low urea $(3.4 \mathrm{mmol} / \mathrm{l})$, a low serum osmolality $(235 \mathrm{mmol} / \mathrm{kg})$ and a high urinary osmolality $(424 \mathrm{mmol} / \mathrm{kg})$. The serum urate was low at $0.18 \mathrm{mmol} / \mathrm{l}$. The serum aspartate aminotransferase, alkaline phosphatase, bilirubin, $B_{12}$, folate, cholesterol, thyroxine, and TSH were normal. The albumin was low at $32 \mathrm{~g} / \mathrm{l}$ and the $\gamma$-glutamyl transferase slightly raised at $50 \mathrm{u}$./l.

The creatinine clearance was $82 \mathrm{ml} / \mathrm{min}$. The 24-hr urinary sodium the day after admission was $85 \mathrm{mmol}$. A chest X-ray showed emphysema with a normal sized heart. A tetracosactrin (Synacthen) test was normal. An emergency pertechnetate brain scan showed possible increased uptake in the right lobe. A CT brain scan revealed considerable cortical atrophy and excluded a subdural haematoma.

A putative diagnosis of Wernicke's encephalopathy was made and intravenous therapy with vitamin B complex begun. Fluid restriction to $500 \mathrm{ml} /$ day was instituted. The patient's conscious level and ataxia and eye signs rapidly improved through a phase of nystagmus. He also developed a diuresis as his plasma : urine osmolality ratio reversed. The serum sodium steadily rose to normal over 3 weeks while daily vitamin B therapy continued. Water restriction was abandoned after 48 hr.

At discharge 3 weeks after admission the patient had a slightly wide-based gait with some residual impairment of short-term memory and a tendency to confabulate.

\section{Discussion}

The characteristic clinical picture in a vagrant with alcoholism, cortical atrophy on CT scan and a rapid improvement following $\mathbf{B}$ vitamin complex, was felt to be diagnostic of Wernicke's encephalopathy, although studies for pyruvate concentrations and transketolase were not performed.

The inappropriate urinary osmolality in the face of serum hypo-osmolality, the low urate (Beck, 1979), absence of fluid depletion with normal renal, thyroid, hepatic and adrenal function is considered good evidence for the syndrome of inappropriate antidiuretic hormone secretion.

It has been suggested (Shalhoub and Antoniou, 1969; Ebels, 1978; Leading Article, 1979) that the syndrome of inappropriate antidiuretic hormone secretion might be expected to occur occasionally in Wernicke's encephalopathy as does hypothermia 
TABLE 1. Changes in serum and urine osmolality

\begin{tabular}{lcccc}
\hline & $\begin{array}{c}\text { Serum Na } \\
(\mathrm{mmol} / \mathrm{l})\end{array}$ & Weight $(\mathrm{kg})$ & $\begin{array}{c}\text { Urine } \\
\text { Osmolality } \\
(\mathrm{mmol} / \mathrm{kg})\end{array}$ & $\begin{array}{c}\text { Serum } \\
\text { Osmolality } \\
(\mathrm{mmol} / \mathrm{kg})\end{array}$ \\
\hline Day 1 & 115 & - & - & - \\
Day 1 & 118 & - & 424 & 235 \\
Thiamine and fluid restriction begun & & & \\
Day 2 & 121 & 45.4 & 237 & 249 \\
Day 3 & 126 & 43.5 & - & - \\
Day 8 & 136 & 44.0 & $366^{*}$ & - \\
Day 15 & 137 & 44.0 & - & - \\
\hline
\end{tabular}

*On 24-hr urinary collection.

(Philip and Smith, 1973). Victor, Adams and Collins (1971) found the characteristic lesions in the supraoptic nuclei of the hypothalamus in $16.7 \%$ and in the paraventricular nucleus in $35 \%$ of their patients with Wernicke's encephalopathy at post-mortem.

The syndrome of inappropriate antidiuretic hormone secretion has been observed in various cerebral conditions and may present with confusion, fits and upgoing plantar responses (Bartter and Schwartz, 1967). It has been observed in hypothalamic lesions in particular, such as in acute intermittent porphyria with neuronal loss in the supraoptic and paraventricular nuclei (Perlroth et al., 1966), in neurohypophyseal choristoma (Haslett and Douglas, 1978) and in hypothalamic glioma (Brisman and Chuturian, 1970). Similarly the syndrome of inappropriate antidiuretic hormone secretion has been produced in goats by inducing lesions in the region of the supra-optic nuclei (Rundgren and Fyhrquist, 1978).

Although hyponatraemia may give rise to neurological signs, an underlying neurological lesion causing the hyponatraemia should not be forgotten, least of all Wernicke's encephalopathy where intravenous vitamin B complex may be life-saving. There are several cases in the literature of the syndrome of inappropriate antidiuretic secretion where Wernicke's encephalopathy was not apparently excluded (Hamilton, 1978; Decaux et al., 1981).

\section{Acknowledgment}

We thank Dr Michael J. Williams for permission to report this patient who was under his care.

\section{References}

BARTter, F.C. \& Schwartz, W.B. (1967) The syndrome of inappropriate secretion of antidiuretic hormone. American Journal of Medicine, 42, 790.

BECK, L.H. (1979) Hypouricemia in the syndrome of inappropriate secretion of antidiuretic hormone. New England Journal of Medicine, 301, 528.

Brisman, R. \& Chuturian, A.M. (1970) Inappropriate antidiuretic hormone (hypothalamic glioma in a child). Archives of Neurology (Chicago), 23, 63.

Decaux, G., Waterlot, Y., Genette, F. \& Mockel, J. (1981) Treatment of the syndrome of inappropriate $\zeta$ secretion of antidiuretic hormone with furosemide. New England Journal of Medicine, 304, 329.

EbeLs, E.J. (1978) How common is Wernicke-Korsakof syndrome? Lancet, ii, 781.

HAMILTON, D.V. (1978) Inappropriate secretion of ant 성 diuretic hormone associated with cerebellar and cerebrg. atrophy. Postgraduate Medical Journal, 54, 427.

HasletT, C. \& Douglas, N.J. (1978) Inappropriate ADH secretion associated with neurohypophyseal choristoma. British Medical Journal, 2, 1753.

LEADING ARTICLE (1979) Wernicke's encephalopathy. British Medical Journal, 2, 291.

Perlroth, M.G., Tschudy, D.P., Marver, H.S., Berard, C.W., Zeigel, R.F., Rechcigl, M. \& Collins, A. (1966) Acute intermittent porphyria: new morphologic and bio- $\bar{Z}$ chemical findings. American Journal of Medicine, 41, 149.

Philip, G. \& SMITH, J.F. (1973) Hypothermia and Wernicke's encephalopathy. Lancet, ii, 121.

RUNDGREN, M. \& FyHRQUisT, F. (1978) Transient water diuresis and syndrome of inappropriate antidiuretic $\bar{\sigma}$ hormone induced by forebrain lesions of different location. Acta physiologica scandinavica, 103, 421.

Shalhoub, R.J. \& Antoniou, L.D. (1969) The mechanism of hyponatremia in pulmonary tuberculosis. Annals of Internal Medicine, 70, 943.

Victor, M., Adams, R.D. \& Collins, G.H. (1971) The Wernicke-Korsakoff Syndrome. Blackwell Scientific Pub- 을 lications, Oxford. 